\title{
Efficacy of ultrasound-guided bilateral erector spinae plane block in pediatric laparoscopic cholecystectomy: Case series
}

\author{
Pediatrik laparoskopik kolesistektomi için ulltrason rehberliğinde yapılan bilateral \\ erector spina plan bloğun etkinliği: Vaka serileri
}

(D) Ömer KARACA, ${ }^{\circledR}$ - Hüseyin Ulaş PINAR²

\begin{abstract}
Summary
Postoperative opioid administration can cause various side effects, such as drowsiness, respiratory distress, postoperative nausea, and vomiting. The use of non-opioid medications as part of a multimodal analgesia method has been increasingly suggested in the management of acute postsurgical pain. Erector spinae plane block (ESPB), which is a regional anesthesia technique, blocks both visceral and somatic nerve fibers. Though it is infrequently used in young patients, presently described is a series of cases in which ESPB was successfully used in the performance of pediatric laparoscopic cholecystectomy. Ultrasound-guided bilateral ESPB was performed on 4 patients who underwent a laparoscopic cholecystectomy. An injection of $0.25 \%$ bupivacaine was administered into the interfascial area on each side in the pre-incisional period after the anesthesia induction (total anesthetic: $2.5 \mathrm{mg} / \mathrm{kg}$ ). Postoperative pain control was planned at $10 \mathrm{mg} / \mathrm{kg}$ intravenous paracetamol every 8 hours. Numeric rating scale pain scores were less than 3 points in the post-anesthetic care unit, and at 1, 2, 4, 8, 12, and 24 hours. No rescue analgesic ( $1 \mathrm{mg} / \mathrm{kg}$ tramadol) was needed. None of the typical complications, such as drowsiness or nausea, were observed and no block-related complications were recorded. Bilateral ESPB that is a part of multimodal analgesia regimen can provide effective analgesia for pediatric laparoscopic cholecystectomy patients in the first 24 hours postoperatively.

Keywords: Erector spinae block; laparoscopic cholecystectomy; pediatrics; postoperative pain; ultrasound.
\end{abstract}

Özet

Ameliyat sonrası opioid uygulaması uyku hali ve solunum sıkıntısı, bulantı ve kusma gibi çeşitli yan etkilere neden olabilir. Multimodal analjezinin bir parçası olarak opioid olmayan ilaçlar, akut cerrahi sonrası ağrının tedavisinde giderek artan ölçüde öne sürülmektedir. Bölgesel bir anestezi tekniği olan Erector spinae plan bloğu (ESPB) hem visseral hem de somatik sinir liflerini bloke eder. Pediatrik cerrahi olgularda çok az uygulaması olan laparoskopik kolesistekomide postoperatif ağrı için bir ESPB vaka serisi sunduk. Laparoskopik kolesistektomi yapılan dört hastaya ultrason eşliğinde bilateral ESPB yapıldı. Anestezi indüksiyonundan sonra, insizyon öncesi dönemde her iki taraftaki fasyalar arasındaki alanına\% 0.25 bupivakain enjekte edildi. (toplam anestezi: $2.5 \mathrm{mg} / \mathrm{kg}$ ) Ameliyat sonrası ağrı kontolü, her sekiz saatte bir $10 \mathrm{mg} / \mathrm{kg}$ 'lık parasetamol ile planlandı. NRS (sayısal puanlama ölçeği) ağrı skorları, anestezi sonrası bakım ünitesinde (PACU) 1, 2, 4, 8, 12 ve 24. saatlerde üç puanın altındaydı. Kurtarma analjeziklerine (1 mg/kg tramadol) intiyaç olmadı. Bu yüzden, uyuşukluk, bulantı ve kusma gibi komplikasyonlar olmadı. Blokla ilişkili herhangi bir komplikasyonla karşılaşılmadı. Multimodal analjezi rejiminin bir parçası olan ESPB'un iki tarafı uygulanması, pediatrik laparoskopik kolesistektomi için postoperatif ilk 24 saatte etkili analjezi sağlamaktadır.

Anahtar sözcükler: Erector spina blok; laparoskopik kolesistektomi; pediatri; postoperatif ağrl; ultrason.

\section{Introduction}

Laparoscopic cholecystectomy is performed mostly in adults and less frequently in pediatric cases. ${ }^{[1]}$ Postoperative pain after laparoscopic cholecystectomy (LC) can be moderate in intensity. The etiology of the pain has been attributed to tissue injury, residual pneumoperitoneum, and stretching of the diaphragm with associated phrenic neuropraxia. [2] Multimodal analgesia in laparoscopic cholecystectomy is usually provided with a combination of paracetamol, nonsteroidal anti-inflammatory drugs, opioids and regional anesthesia methods.

Erector spinae block (ESPB) is a suitable regional anesthesia method which has been observed to have

\footnotetext{
'Deparment of Anaethesia and Reanimation, Private Anit Hospital, Konya, Turkey ${ }^{2}$ Department of Anaesthesia and Reanimation, Baskent University, Konya, Turkey

Submitted: 25.02.2019 Accepted after revision: 28.05.2019 Available online date: 14.06.2019

Correspondence: Dr. Ömer Karaca. Özel Konya Anıt Hastanesi, Anesteziyoloji ve Reanimasyon Anabilim Dalı, Konya, Turkey. Phone: +90 - 530 - 1565776 e-mail: dromerkaraca@hotmail.com

(C) 2019 Turkish Society of Algology 
characteristics of postoperative analgesia in various thoracic and abdominal operations because it blocks both somatic and visceral pain. As a result of local anesthetic injection into the interfascial space between the transverse process of the vertebrae and the erector spinae muscle, ESPB is performed with the spreading of local anesthesia into multiple paravertebral spaces. $^{[3]}$

We wanted to report the ESPB in pediatric patients. We performed pre-incisionally in laparoscopic cholecystectomy operations for cholelithiasis as a case series study. In all of the cases, both the block to be applied and that the cases might be reported have been told to the legally responsible individuals and written consent was obtained.

\section{Case Series}

Four patients, ages of 10,12,14, 11 years and weights of $25,30,45,25 \mathrm{~kg}$ respectively, planned laparoscopic cholecystectomy due to cholecystitis and recurrent attacks of cholecystitis. There were no features in the preoperative evaluations of patients 1, 3 and 4. Only patient 2 had a history of tonsillectomy at the age of 5. The laboratory findings of all the patients were normal. All patients underwent the same preoperative preparation. After electrocardiography, saturation oxygen and non-invasive blood pressure measurements, a 24-gauge peripheral venous line was opened for fluid replacement and drug administration. Ringer's lactate/glucose (4:1) $5 \mathrm{ml} / \mathrm{kg}$ was given intravenously (IV) for fluid replacement. 2-3 $\mathrm{mg} / \mathrm{kg}$ propofol, $1 \mu \mathrm{g} / \mathrm{kg}$ fentanyl and $0.6 \mathrm{mg} / \mathrm{kg}$ rocuronium were used and intubated after anesthesia induction. Afterwards, anesthesia was maintained by ventilation with $0.05 \mu / \mathrm{kg}$ remifentanil (IV) and oxygen mixture with $6 \%$ desflurane in $50 \%$ air. Depending on the hemodynamic parameters, the dose of remifentanil was increased to $1.5 \mu \mathrm{g} / \mathrm{kg}$. Normocarbic ventilation was aimed. After intubation, patients were turned to prone position. The thoracic vertebrae region including the lower end of the scapula was sterilized with povidone iodine. With the help of the lower end of the scapula, the T7 vertebrae spinous process was determined. After the 5-13 $\mathrm{MHz}$ linear ultrasound probe (Fujifilm SonoSite, WA, USA) was coated with a sterile sheath, it was placed over the T7 vertebrae spinous process at the sagittal plane and then was slid by $1.5-2 \mathrm{~cm}$ laterally at

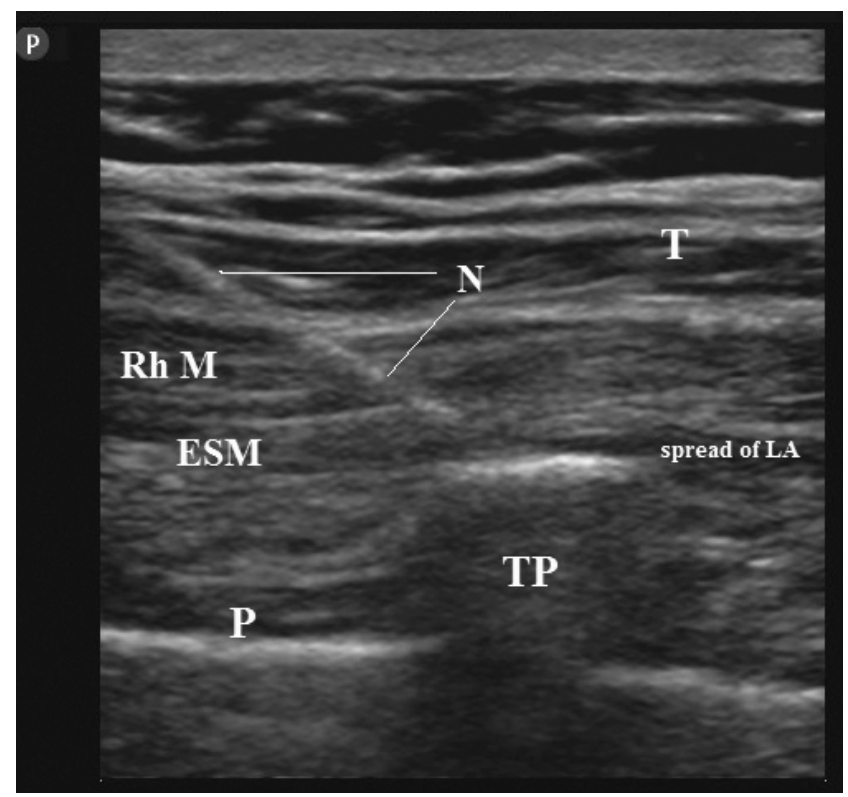

Figure 1. Scanning ultrasonogram displaying Trapezius (T), Rhomboid Major (Rh M) and Erector Spinae Muscle (ESM), Pleura (P), T7 transverse process (TP), Needle (N) and spread of local anesthetic (LA). Erector spinae plane block performs at level of T7 transverse process. The needle inserts with in-plane technique and the tip of needle contacts the TP. Then local anesthetic (LA) injects into the fascial plane on the anterior face of ESM.

the midsagittal region. After the trapezius, rhomboid major, erector spinae muscles and the transverse process of vertebrae were visualized, a 22-gauge 10 cm needle (Stimuplex A, B Braun, Melsungen, Germany) was inserted using in-plane cephal-to-caudal approach. The tip of needle was situated into the fascial plane on the anterior (deep) face of erector spinae muscle. The total dose of $0.5 \%$ bupivacaine used was designed to be $2.5 \mathrm{mg} / \mathrm{kg}$. The local anaesthetic was prepared as $0.25 \%$ bupivacaine for each side. Localization of the needle tip: bupivacaine was injected after separation with hydrodissection was confirmed by giving $0.5-1 \mathrm{ml}$ of fluid to the deep fascia of the erector spinae muscle above the bone shadow of the transverse process of the T7 vertebrae. Spread of the local anesthetic was observed (Fig. 1). The same procedure was repeated on the other side. At the end of the operation, the pneumoperitoneum was evacuated. Patients were extubated after the wounds were sutured and closed and they showed adequate muscle strength, and they were transferred to postanesthesia care unit (PACU). The patients were sent to the wards when the Aldrete Score System was at least 9 in PACU. No nebulized local anesthetic was administered intraperitoneally to the wounds. The patients were discharged after 36 hours of follow-up. 
Table 1. Demographic characteristic of patients

\begin{tabular}{lcccc}
\hline & $\begin{array}{c}\text { 1. } \\
\text { child }\end{array}$ & $\begin{array}{c}\text { 2. } \\
\text { child }\end{array}$ & $\begin{array}{c}\text { 3. } \\
\text { child }\end{array}$ & $\begin{array}{c}\text { 4. } \\
\text { child }\end{array}$ \\
\hline Age, year & 10 & 12 & 14 & 11 \\
Sex & $\mathrm{F}$ & $\mathrm{M}$ & $\mathrm{F}$ & $\mathrm{F}$ \\
Height, cm & 126 & 141 & 150 & 130 \\
Weight, kg & 24 & 33 & 44 & 26 \\
BMl & 15.1 & 16.6 & 19.6 & 15.4 \\
Operation time, min & 85 & 95 & 98 & 85 \\
Anesthesia time, min & 95 & 106 & 110 & 97 \\
\hline
\end{tabular}

BMI: Body mass index; min: Minute.

\section{Pain management}

The Numeric Rating Scale (NRS), which best reflects the severity of the pain of the patients at the PACU, $1^{\text {st }}, 2^{\text {nd }}, 4^{\text {th }}, 8^{\text {th }}, 12^{\text {th }}$ and $24^{\text {th }}$ hours was used to evaluate the postoperative pain. The 11-point numeric scale ranges from ' 0 ' respecting no pain to ' 10 ' respecting the worst imaginable pain. NRSs during movement and rest were evaluated and recorded. If NRS was $\geq 3,1 \mathrm{mg} / \mathrm{kg}$ tramadol (IV) was planned to be administered.

\section{Results}

Age, sex, weight, height, body mass index and ASA scores, surgical and anesthesia durations was shown in Table 1. ESPB block was successfully performed in 4 pediatric patients without any complications such as pneumothorax, bleeding or subcutaneous emphysema.

Looking at the pain assessments at the PACU, $1^{\text {st }}, 2^{\text {nd }}$, $4^{\text {th }}, 8^{\text {th }}, 12^{\text {th }}$ and $24^{\text {th }}$ hours in the postoperative period, the NRS scores were observed to not be at 3 or above during both rest and movement (coughing/movement). No rescue analgesic was needed. None of the patients had shoulder pain, nausea or vomiting.

\section{Discussion}

Our case series have shown that ESPB block provide long-term analgesia in pediatric laparoscopic cholecystectomy.

If acute postoperative pain after laparoscopic cholecystectomy is inadequate treatment, side effects and serious problems is encountered, which include: increased incidence of persistent postoperative pain; rehabilitation defect; hospital stay or recurrent hospitalization; intact quality of life; and excessive sedation, nausea, vomiting and itching due to opioid. In such cases, if analgesic treatment is initiated after a painful stimulus, treatment of postoperative pain may be difficult due to the possibility of peripheral hypersensitivity and central nervous system hyperexcitability. Postoperative effective pain control offers benefits such as earlier mobilization, increased patient satisfaction, lower hospital costs and shorter hospital stay. ${ }^{[4]}$

Although laparoscopic cholecystectomy has advantages over open surgery, acute pain caused by the procedure is common. The peak of pain intensity following laparoscopic cholecystectomy is between the first and eighth hours and usually decreases 2 or 3 days after surgery. Pain is usually seen in the back, shoulder and port incision regions. Sympathetic pain occurs in approximately $30-50 \%$ of patients and this can be difficult to cope with. Severe acute postoperative pain that may occur weeks or months after surgery may lead to chronic pain. ${ }^{[4]}$ Therefore, the treatment of acute pain in especially pediatric patients is a very important issue.

Peripheral blocks form a part of the multimodal analgesic regimen. Regional blocks do not only reduce the use of other analgesics such as opoid, but also prevent their side effects. Studies have been conducted on the efficiency of transversus abdominis plane block (TAP) and ultrasound-guided oblique subcostal transversus abdominis plane block (OSTAP) for laparoscopic cholecystectomy; $;^{[3]}$ however, both blocks have the ability to affect the cutaneous fibers and are therefore more effective on somatic pain. Ortiz et al. revealed that TAP block had no significant analgesic activity for this purpose. ${ }^{[5]}$ Altiparmak et al. showed that ESPB block was more effective on postoperative tramadol consumption and pain scores than OSTAP block in adult patients undergoing laparoscopic cholecystectomy. They also thought that the dermatomal extension of the local anesthetic in the ESPB block is greater than the OSTAP block. ${ }^{[6]}$ Because ESPB block is targeted to ventral, dorsal ramie and ramie communicators of spinal nerves. On the other hand, OSTAP block affects somatic and parietal components of postoperative pain and has no effect on visceral component. ${ }^{[6,7]}$ 
Another method is the paravertebral block which is a denser block. Although this block is performed under ultrasound, there are serious complications such as vascular, neuronal and plevral puncture, cardiac depression, epidural or intrathecal dissemination. ${ }^{[8]}$ Visoiu et al. compared bilateral paravertebral block and local anesthesia to the port sites in pediatric LC. They showed that PVB has no significant superiority to local anesthetic infiltration. ${ }^{[2]}$

While Ueshima and Hiroshi block supported paravertebral extension of local anesthesia for ESPB. ${ }^{[9]}$ Forea et al. reported that the spinal nerves spread to both ventral and dorsal ramies. ${ }^{[7]}$ In a recent cadaveric study, Ivanusic et al. showed that local anesthesia did not spread to paravertebral space and ventral ramie. ${ }^{[10]}$ On the other hand, in an magnetic resonance imaging and anatomical study have been reported epidural and intercostal spread. ${ }^{[1]]}$ In another study, when the ESPB block was performed at the lower thoracic level, it was revealed that the local anesthetic extended to the anterior and entered the thoracic paravertebral space. So, it is stated that ramie communicants was also blocked. ${ }^{[12]}$ Because author ESPB block applied at lower thorasic level (T7), author thought that the block provided adequate analgesia by acting on visceral, parietal and somatic pain as a result of the spread of the local anesthetic over a large area.

Pneumothorax and motor weakness were two complicaitons reported for ESPB block. ${ }^{[13,14]}$ Since the block is performed under ultrasound, it is difficult to encounter pneumothorax. However, it can occur as a result of carelessness. Motor weakness may occur when the block applied lower thoracic and lumbar level, which local anesthesia is allowed to spread to the lumbar plexus. ${ }^{[15]}$ Author did not encounter any complications related to block in any of the cases.

Local Anesthesia Systemic Toxicity (LAST), which is caused by local anesthesia spreading and high volume application is also mentioned.Aksu and Gurkan applied $0.5 \mathrm{ml} / \mathrm{kg} 0.25 \%$ with a maximum bupivacaine dose of $20 \mathrm{ml} /$ per side in ESPB block for pediatric LC ve herhangi bir LAST ile karşılammışlardır. ${ }^{[17]}$ Thomas and Tulgar performed ESPB block by applying $15 \mathrm{ml}$ of bilateral, $30 \mathrm{ml}$ of total $0.25 \%$ bupivacaine to a $23 \mathrm{~kg}$ pediatric patient exposed to lapa- roscopic cholecystectomy. ${ }^{[17]}$ Although they did not observe LAST, the maximum dose of bupivacaine was seen to be exceeded in this volume. However, the maximum dose for bupivacain is $3 \mathrm{mg} / \mathrm{kg} .{ }^{[18]} \mathrm{Tul}-$ gar et al. applied $2.5 \mathrm{mg} / \mathrm{kg}$ for bupivacaine plus 4 $\mathrm{mg} / \mathrm{kg}$ for lidocaine during ESPB block permormed and run across LAST related sentral nervous system toxicity such as aphasia/apthia, short-lasting loss of conciousness and tinnitus/vertigo. ${ }^{[15]}$ The author performed a total of $2.5 \mathrm{mg} / \mathrm{kg}$ of $0.25 \%$ bupivacain to the bilateral ESPB block. The complications related to the cardiovascular system such as hypotension, dysrhythmia and cardiac arrest during the peroperative period, and central nervous system complications such as disorientation, tinnitus and seizures during postoperative period were not encountered.

The ESPB block can only act in the paraspinal area, but may also block the lateral side of the thoracoabdominal areas and the mid-abdomen. Therefore, block failure/lack of efficiency was defined the first time by Tulgar et al. ${ }^{[15]}$ Author did not evaluate dermatom areas in the postoperative period. However, author indicated that the block was effective, due to the postoperative NRS scores $<3$ and the absence of any analgesics requirement.

Our cases needed no analgesic in the postoperative period either. Dissimilar to the literature, we found that sufficient analgesia was provided at $24^{\text {th }}$ postoperative hour in pediatric patients exposed to LC as a result of total $2.5 \mathrm{mg} / \mathrm{kg}$ bupivacaine bilateral administration. ESPB block is a safe and effective regional anesthesia method for multimodal analgesia. The results obtained from our case series will be useful for randomized studies.

\section{Informed Consent: Written informed consent was obtained from the patient for the publication of the case report and the accompanying images.}

Conflict-of-interest issues regarding the authorship or article: None declared.

\section{Peer-rewiew: Externally peer-reviewed.}

\section{References}

1. Zeidan MM, Pandian TK, Ibrahim KA, Moir CR, Ishitani MB, Zarroug AE. Laparoscopic cholecystectomy in the pediatric population: a single-center experience. Surg Laparosc Endosc Percutan Tech 2014;24(3):248-50. [CrossRef] 
2. Visoiu M, Cassara A, Yang Cl. Bilateral Paravertebral Blockade (T7-10) Versus Incisional Local Anesthetic Administration for Pediatric Laparoscopic Cholecystectomy: A Prospective, Randomized Clinical Study. Anesth Analg 2015;120(5):1106-13. [CrossRef]

3. Tulgar S, Kapakli MS, Senturk O, Selvi O, Serifsoy TE, Ozer Z. Evaluation of ultrasound-guided erector spinae plane block for postoperative analgesia in laparoscopic cholecystectomy: A prospective, randomized, controlled clinical trial. J Clin Anesth 2018;49:101-6. [CrossRef]

4. Karaca O, Pınar HU, Turk E, Dogan R, Ahiskalioglu A, Solak SK. The Effects of Pregabalin Plus Ibuprofen on Acute Pain after Laparoscopic Cholecystectomy. J Invest Surg 2019;32(3):189-95. [CrossRef]

5. Ortiz J, Suliburk JW, Wu K, Bailard NS, Mason C, Minard CG, et al. Bilateral transversus abdominis plane block does not decrease postoperative pain after laparoscopic cholecystectomy when compared with local anesthetic infiltration of trocar insertion sites. Reg Anesth Pain Med 2012;37(2):188-92. [CrossRef]

6. Altıparmak B, Korkmaz Toker M, Uysal Al, Kuşçu Y, Gümüş Demirbilek S. Ultrasound-guided erector spinae plane block versus oblique subcostal transversus abdominis plane block for postoperative analgesia of adult patients undergoing laparoscopic cholecystectomy: Randomized, controlled trial. J Clin Anesth 2019;57:31-6. [CrossRef]

7. Forero M, Adhikary SD, Lopez H, Tsui C, Chin KJ. The erector spinae plane block.Reg Anesth Pain Med 2016;41(5):6217. [CrossRef]

8. Kulhari S, Bharti N, Bala I, Arora S, Singh G. Efficacy of pectoral nerve block versus thoracic paravertebral block for postoperative analgesia. Br J Anaesth 2016;117(3):382-6.
9. Ueshima $\mathrm{H}$, Hiroshi O. Spread of local anesthetic solution in the erector spinae plane block. J Clin Anesth 2018;45:23.

10. Ivanusic JJ, Konishi Y, Barrington MJ. A cadaveric study investigating the mechanism of action of erector spinae blockade. Reg Anesth Pain Med 2018;43(6):567-71. [CrossRef]

11. Adhikary SD, Bernard S, Lopez H, Chin KJ. Erector Spinae Plane Block Versus Retrolaminar Block: A Magnetic Resonance Imaging and Anatomical Study. Reg Anesth Pain Med 2018;43(7):756-62. [CrossRef]

12. Chin KJ, Malhas L, Perlas A. The erector spinae plane block provides visceral abdominal analgesia in bariatric surgery a report of 3 cases. Reg Anesth Pain Med 2017;42(3):372-6.

13. Ueshima $H$. Pneumothorax after the erector spinae plane block. J Clin Anesth 2018;48:12. [CrossRef]

14. Selvi O, Tulgar S. Ultrasound guided erector spinae plane block as a cause of unintended motor block. Rev Esp Anestesiol Reanim 2018;65:589-92. [CrossRef]

15. Tulgar S, Selvi O, Senturk O, Serifsoy TE, Thomas DT. UItrasound-guided Erector Spinae Plane Block: Indications, Complications, and Effects on Acute and Chronic Pain Based on a Single-center Experience. Cureus 2019;11(1):e3815.

16. Aksu C, Gürkan Y. Ultrasound-guided bilateral erector spiane block could provide effective postoperative analgesia in laparoscopic cholecystectomy in pediatric patients. Anaesth Crit Care Pain Med 2019;38(1):87-8. [CrossRef]

17. Thomas DT, Tulgar S. Ultrasound-guided Erector Spinae Plane Block in a Child Undergoing Laparoscopic Cholecystectomy. Cureus 2018;10(2):e2241. [CrossRef]

18. Butterworth JF, Mackey DC, Wasnick JD. Morgan and Mikhail's Clinical Anesthesiology. 5th ed. New York, ABD: McGraw-Hill Education; 2013. p.272. 